\title{
Genomic Instability in Buccal Mucosal Cells of Municipal Street Sweepers as Evaluated by Micronucleus Test
}

\author{
VICTOR HUGO PEREIRA DA SILVA ${ }^{1}$, MARIANA CARVALHO ANDRADE ${ }^{2}$, \\ SAMUEL RANGEL CLAUDIO ${ }^{3}$, VERONICA QUISPE YUJRA ${ }^{3}$, MARIA ESTHER SUAREZ ALPIRE ${ }^{1}$, \\ JEAN NUNES DOS SANTOS ${ }^{2}$, PATRICIA RAMOS CURY ${ }^{2}$ and DANIEL ARAKI RIBEIRO ${ }^{1}$ \\ ${ }^{1}$ Department of Biosciences, Federal University of Sao Paulo, UNIFESP, Santos, Brazil; \\ ${ }^{2}$ Post-graduate Program in Dentistry and Health, Federal University of Bahia, UFBA, Salvador, Brazil; \\ ${ }^{3}$ Department of Pathology, Paulista Medical School, UNIFESP, Santos, Brazil
}

\begin{abstract}
Background/Aim: Since street sweepers comprises a group of workers who are in daily contact with rubbish, dust and air pollution, the aim of this study was to evaluate potential cytotoxic and mutagenic effects in buccal mucosa cells of street sweepers. Materials and Methods: A total of 20 male street sweepers aged from 22 to 56 years were included in the experimental group. A total of 20 men matched by age were used as the control group. Cytotoxicity and mutagenicity were analyzed by micronucleus test in buccal mucosal cells. Results: Statistically significant differences $(p<0.05)$ in the frequency of micronuclei was detected in the street sweepers when compared to the control group. No remarkable differences were found to other metanuclear alterations indicative for cytotoxicity such as pyknosis, karyolysis, and karryorhexis when compared to matched controls. Conclusion: Taken together, our results indicate that street sweepers comprise an at-risk group as a result of increased mutagenicity found to buccal mucosa cells.
\end{abstract}

Street junk comprises sediments, heavy metals, organic constituents as well as different kinds of garbage that is deposited by pedestrians or even vehicle occupants $(1,2)$. It is well established that litter from a paved surface has a severe impact against human health (3-5). This is due to the fact that rubbish contains toxic substances, that are in close contact with human populations $(6,7)$. The intake of dust

Correspondence to: Daniel Araki Ribeiro, DDS, Ph.D., Departamento de Biociências, Universidade Federal de São Paulo UNIFESP, Av. Ana Costa 95, 11060-001, Santos - SP, Brazil. Tel/Fax: +55 1338783823, e-mail: daribeiro@unifesp.br

Key Words: Oral mucosa cells, street sweepers, micronucleus test, biomonitoring. particles, spoiled food or harmful gases from street junk poses a potential menace to human health (8). In this context, it is important to keep the streets clean for promoting human health. To fulfill this scenario, municipal governments have employed the professional "street sweeper", who is responsible for cleaning streets on the cities around the world in order to minimize the contact of the people with street junk.

During the last decades, Brazilian cities have grown exponentially, as a result of the construction of new houses and commercial areas as well as expansion of public transportation. Herein, new sources of potentially toxic pollution in the streets may be present. Therefore, biomonitoring studies are very important to evaluate the risk assessment of professionals who are in close contact with street junk for evaluating the risk of inhalation, close contact and/or ingestion of rubbish and related compounds with accuracy, particularly because there are no previous reports.

Many methodologies are accepted by the scientific community and, therefore, recommended for evaluating human risk assessment so far. Among them, micronucleus assay using buccal mucosa cells have been highlighted as safe, low cost, reproducible and non-invasive biomarker for evaluating cytogenetic damage (9). Micronuclei are defined as small nuclei containing fragments or whole chromosomes, which are not included into the main nuclei after mitosis. The formation of micronuclei is induced by physical, chemical and/or biological substances. In order to further promote end-points for the assay, Tolbert et al. (10) increased the specificity of this test by analyzing other metanuclear alterations indicative of cytotoxicity rather than micronuclei, such as pyknosis, karyolysis and karyorrhexis.

Because of the lack of scientific evidence regarding the cytogenetic damage of street sweepers, the aim of this study was to investigate mutagenicity and cytotoxicity in buccal mucosa cells of street sweepers by micronucleus assay. 


\section{Materials and Methods}

Participants. The subjects of this study consisted of 20 men aged 22 to 56 years (mean $\pm \mathrm{SD}=35.7 \pm 35.7$ years). The study's eligibility criteria included: (i) having worked at least 4 months as a street sweeper in the city of Salvador, Bahia State, Brazil (iii) 20-60 years of age; (iii) do not present any systemic disease such as hypertension, diabetes or cancer, (iv) do not use any drugs continuously; (v) do not present any oral lesion at clinical examination; (vi) to be exposed to dental X-ray at least 1 month after collecting buccal cells; (vii) the consent to participate in the study. The control group consisted of 20 healthy men matched by age to the members of the experimental group (aged 33.6 \pm 15.3 years), not occupationally exposed to street junk, but they were included in the same eligibility criteria established for this study. None of the volunteers were smokers. Exposure to other known genotoxic agents such as alcohol consumption or illicit drugs was not recorded in this setting. The study was approved by the Ethics Committee of the Federal University of Bahia, Brazil. Informed consent was obtained from the individuals included in the study.

Micronucleus test on oral mucosal cells. After rinsing the mouth with tap water, cells were obtained from each participant by scraping the mucosa of the right/left cheek with a moist wooden spatula. Cells were transferred to a tube containing saline solution, which was then centrifuged $(850 \times g)$ for $5 \mathrm{~min}$, fixed in $3: 1$ methanol/acetic acid, and dropped onto pre-cleaned slides. After that, the air-dried slides were stained using the Feulgen/Fast-Green method. For this purpose, slices were immersed at $\mathrm{HCl} 5 \mathrm{~N}$ solution for $15 \mathrm{~min}$, rinsed in distilled water for $1 \mathrm{~min}$; placed in Schiff's reagent (Merck, Darmstadt, Germany) for $90 \mathrm{~min}$, washed again in water for $3 \mathrm{~min}$ and counterstained with $1 \%$ fast green for $1 \mathrm{~min}$.

Data analysis. All slides were examined under a light microscope at $\times 1000$ magnification to determine the frequency of micronucleated cells and metanuclear alterations indicated of cytotoxicity. Micronuclei were scored according to the criteria described by Belien et al. (9) as a parameter of DNA damage (mutagenicity). For cytotoxicity, the following nuclear alterations were considered: pyknosis, karyolysis and karyorrhexis. Results were expressed as a percentage of the total cells examined. This analysis was established in a previous study conducted by our research group being performed by one experienced observer (11). A total of 2000 cells was evaluated per volunteer.

Statistical methods. The Mann-Whitney non-parametric test was used to compare the frequencies of cytotoxicity among the samples between the experimental group versus the control group. Micronucleus frequencies between controls and street sweepers were evaluated as established by Pereira et al. (12). The statistical analysis was conducted using BioStat software, version 5.0 (Maringa, PR, Brazil). The level of statistical significance was set at $5 \%$.

\section{Results}

The micronucleus test in buccal mucosa cells was applied in this setting to evaluate mutagenicity and cytotoxicity induced by street cleaning cities. The results showed an increase of
Table I. Micronucleus incidence (mean $\pm S D$ ) in buccal mucosal cells of street sweepers.

\begin{tabular}{lc}
\hline Group & Micronucleus incidence $(\%)$ \\
\hline Controls $(\mathrm{n}=20)$ & $0.1 \pm 0.2$ \\
Street sweepers $(\mathrm{n}=20)$ & $0.26 \pm 1.1 *$ \\
\hline
\end{tabular}

$* p<0.05$ when compared to control group.

Table II. Cytotoxicity (mean $\pm S D)$ as reflected in karrhyorexis, pyknosis and karyolysis in buccal mucosa cells of street sweepers.

\begin{tabular}{lccc}
\hline Groups & $\begin{array}{c}\text { Pyknosis } \\
(\%)\end{array}$ & $\begin{array}{c}\text { Karrhyorexis } \\
(\%)\end{array}$ & $\begin{array}{c}\text { Karyolysis } \\
(\%)\end{array}$ \\
\hline Controls (n=20) & $17.1 \pm 3.8$ & $2.0 \pm 1.7$ & $4.9 \pm 2.7$ \\
Street sweeper (n=20) & $22.5 \pm 27.9$ & $2.9 \pm 4.9$ & $8.6 \pm 8.2$ \\
\hline
\end{tabular}

$p>0.05$.

micronucleated cells with statistically significant differences $(p<0.05)$ in buccal mucosa cells of street sweepers when compared to matched controls. The results are demonstrated in Table I.

When cytotoxicity parameters were evaluated, interesting results were seen. Pyknosis was not altered in the street sweepers group when compared to matched controls. Such findings showed no statistically significant differences $(p>0.05)$ between groups. In the same way, no statistically significant differences $(p>0.05)$ were found to karyolysis and karrhyorexis, since no remarkable differences were found between groups $(p>0.05)$. Such findings are shown in Table II.

Finally, age and duration of work did not show remarkable differences intra-group (data not shown).

\section{Discussion}

The aim of this study was to investigate chromosomal damage and cellular death induced by occupational exposure to municipal street sweeper as indicators of mutagenicity and cytotoxicity, respectively. The investigation was conducted using the micronucleus test in oral mucosal cells. To the best of our knowledge, there are many studies investigating the effectiveness of street sweepers in removing pollutants from road surfaces or heavy metals concentration in street dust from cities around the world (13-16), but no studies have evaluated mutagenicity and cytotoxicity in street sweepers so far.

The micronucleus assay is widely applied by the scientific community since it represents an easy, non-invasive, cheap 
and reproducible method when evaluating cytogenetic damage in human populations (9). Micronuclei represent genetic material from DNA breakage after mitosis, as a result of chromosomal breakage or loss (9). Pathological events able to induce micronuclei in epithelial cells occurs in the basal layer of oral epithelium. During the turnover process of epithelial tissues, micronucleated cells migrate into the superficial layers of epithelium thus being possible to evaluate the micronucleus frequency after scrapping the oral mucosa. The detection is made by subjective microscopic analysis being very important to stain slides with a specific DNA dye in order to avoid potential bias when analyzing the results (9).

Taking into consideration the carcinogenesis process, genetic damage is the first step followed by mutagenesis induced by chemicals. In general, DNA damage is provided from environmental exposure to genotoxins, mutagens, and/or carcinogens (17). Micronuclei confirm mutagenesis in cells and living tissues, which corresponds to the initiation phase of carcinogenesis (18). For this reason, the detection of an elevated frequency of micronuclei in eukaryotic cells indicates genomic instability as far as increased cancer risk (19). Our results demonstrated an increased micronucleus frequency in buccal cells of street sweepers when compared to those from matched controls. This finding is totally new and therefore difficult to discuss. Some studies have demonstrated that the composition of street is very variable and originates from different sources depending on climate and human activities $(20,21)$. Human activities contribute significantly to an increase in toxic materials in the dust, especially in the form of potentially toxic metals (22). Atmospheric pollution is also one of the major sources of metal contamination in soils and street dust by sedimentation, impaction and interception (22). This could explain our results.

In order to monitor cytotoxic effects, the frequencies of karyorrhexis, karyolysis and pyknosis were performed in this study. In an earlier study conducted by our research group, it was demonstrated that waste collectors increased metanuclear alterations indicative of cytotoxicity (23). Such findings motivated us to investigate if, and to what extent, street sweepers possess elevated cytotoxicity in buccal mucosa cells as well. Our results showed that daily contact with street junk did not increase any metanuclear alterations indicative of cytotoxicity. Some authors have postulated that continuous exposure to genotoxic agents induces chromatin shrinkage followed by disruption of the nuclear membrane may result in cytotoxicity (24). In fact, it has been postulated that chronic exposure to genotoxins induced an increase in cell death in buccal epithelium of humans (25). However, our results did not find any positive results closely related to cytotoxic parameters induced by continuous exposure to rubbish as an indicative of cellular death. Further studies are welcomed to elucidate the issue.
In conclusion, the results of the present study suggest that exposure to street junk increases the frequency of micronucleated cells in buccal mucosa cells. This reinforces the need to evaluate the side-effects on health induced by occupational exposure to street junk. Overall, street sweepers should be examined regularly in order to prevent several diseases related to continuous chemical or biological exposure.

\section{Conflicts of Interest}

None declared.

\section{References}

1 Vanegas Useche LV, Wahab MM and Parker GA: Effectiveness of gutter brushes in removing street sweeping waste. Waste Manag 30(2): 174-184, 2010

2 Vanegas-Useche LV, Abdel-Wahab MM and Parker GA: Effectiveness of oscillatory gutter brushes in removing street sweeping waste. Waste Manag 43: 28-36, 2015.

3 Al-Khatib IA, Arafat HA, Daoud R and Shwahneh H: Enhanced solid waste management by understanding the effects of gender, income, marital status, and religious convictions on attitudes and practices related to street littering in Nablus - Palestinian territory. Waste Manage 29(1): 449-455, 2009.

4 Carvalho P, Marques RC and Dollery B: Is bigger better? An empirical analysis of waste management in New South Wales. Waste Manage 39: 277-286, 2015.

5 Parthan SR, Milke MW, Wilson DC and Cocks JH: Cost estimation for solid waste management in industrialising regions - precedents, problems and prospects. Waste Manage 32: 584$594,2012$.

6 Ferreira-Baptista L and De Miguel E: Geochemistry and risk assessment of street dust in Luanda, Angola: a tropical urban environment. Atmospheric Environment 39: 4501-4512, 2005.

7 Sammut ML, Noack Y, Rose J, Hazemann JL, Proux O, Depoux $\mathrm{M}$, Ziebel $\mathrm{A}$ and Fiani E: Speciation of $\mathrm{Cd}$ and $\mathrm{Pb}$ in dust emitted from sinter plant. Chemosphere 78(4): 445-450, 2010.

8 Faiz Y, Siddique N and Tufail M: Pollution level and health risk assessment of road dust from an expressway. J Environ Sci Health A Tox Hazard Subst Environ Eng 47(6): 818-829, 2012.

9 Beliën JA, Copper MP, Braakhuis BJ, Snow GB and Baak JP: Standardization of counting micronuclei: definition of a protocol to measure genotoxic damage in human exfoliated cells. Carcinogenesis 16(10): 2395-400, 1995.

10 Tolbert PE, Shy CM and Allen JW: Micronuclei and other nuclear anomalies in buccal smears: methods development. Mutat Res 271: 69-77, 1992.

11 Souza AC, DA Silva VH, Seixas C, DE Oliveira Scudeller TT, DO Amaral MT and Ribeiro DA: Cytogenetic Biomonitoring in Buccal Mucosa Cells from Women Submitted to Chemotherapy After Mastectomy for Breast Cancer. Anticancer Res 36(4): 1955-1958, 2016.

12 Pereira CAB: Teste estatístico para comparar proporções em problemas de citogenética. In: Rabelo-Gay N, Rodrigues MA and Monteleone-Neto R (eds.) Mutagênese, Teratogênese e Carcinogênese. SBG, pp. 113-121, 1991 (in Portuguese). 
13 Abdel-Wahab MM, Wang C, Vanegas-Useche LV and Parker GA: Experimental determination of optimum gutter brush parameters and road sweeping criteria for different types of waste. Waste Manag 31(6): 1109-1120, 2011.

14 Prichard HM, Sampson J and Jackson M: A further discussion of the factors controlling the distribution of $\mathrm{Pt}, \mathrm{Pd}, \mathrm{Rh}$ and $\mathrm{Au}$ in road dust, gullies, road sweeper and gully flusher sediment in the city of Sheffield, UK. Sci Total Environ 407(5): 1715-1725, 2009.

15 German J and Svensson G: Metal content and particle size distribution of street sediments and street sweeping waste. Water Sci Technol 46(6-7): 191-198, 2002.

16 Tobin GA and Brinkmann R: The effectiveness of street sweepers in removing pollutants from road surfaces in Florida. J Environ Sci Health A Tox Hazard Subst Environ Eng 37(9): 1687-700, 2002.

17 Kujan O, Oliver RJ, Khattab A, Roberts SA, Thakker N and Sloan A: Evaluation of a new binary system of grading oral epithelial dysplasia for prediction of malignant transformation. Oral Oncol 42: 987-993, 2006.

18 Carbajal-López Y, Gómez-Arroyo S, Villalobos-Pietrini R, Calderón-Segura ME and Martínez-Arroyo A: Biomonitoring of agricultural workers exposed to pesticide mixtures in Guerrero state, Mexico, with comet assay and micronucleus test. Environ Sci Pollut Res Int 23(3): 2513-2520, 2016.

19 Wultsch G, Nersesyan A, Kundi M, Wagner KH, Ferk F, Jakse $\mathrm{R}$ and Knasmueller S: Impact of exposure to wood dust on genotoxicity and cytotoxicity in exfoliated buccal and nasal cells. Mutagenesis 30(5): 701-709, 2015.
20 Acosta JA, Faz Á, Kalbitz K, Jansen B and Martínez-Martínez S: Heavy metal concentrations in particle size fractions from street dust of Murcia (Spain) as the basis for risk assessment. J Environ Monit 13(11): 3087-3096, 2011.

21 Yongming H, Peixuan D, Junji C and Posmentier ES: Multivariate analysis of heavy metal contamination in urbandusts of Xi'an, Central China. Sci Total Environ 355(1-3): 176-186, 2006.

22 Adachi K and Tainosho Y: Single particle characterization of size-fractionated road sediments. Appl Geochem 20: 849-859, 2005.

23 Andrade MC, Dos Santos JN, Cury PR, Flygare AC, Claudio SR, Oshima CT and Ribeiro DA: Cytogenetic Biomonitoring in Buccal Mucosal Cells from Municipal Solid Waste Collectors. Anticancer Res 37(2): 849-852, 2017.

24 Cerqueira EM, Gomes-Filho IS, Trindade S, Lopes MA, Passos JS and Machado-Santelli GM: Genetic damage in exfoliated cells from oral mucosa of individuals exposed to X-rays during panoramic dental radiographies. Mutat Res 562(1-2): 111-117, 2004.

25 Sycheva LP, Umnova NV, Kovalenko MA, Zhurkov VS, Shelepchikov AA and Roumak VS: Dioxins and cytogenetic status of villagers after 40 years of Agent Orange application in Vietnam. Chemosphere 144: 1415-1420, 2016.

Received March 15, 2018

Revised April 19, 2018

Accepted April 20, 2018 